\title{
College English Teacher's Accomplishments in the Information Age
}

\author{
Yan YUE \\ School of Foreign Language \& Literature, Baoji University of Arts \& Sciences, Baoji, Shaanxi, China \\ 398318705@qq.com
}

Keywords: Teacher's Accomplishments, College English Teaching, Information Age

\begin{abstract}
English, as one of the most widely used languages in the world, is an important tool for international communication, science and technology and cultural exchanges. English learning not only meets the requirements of cultivation of national strategic talents, but it also satisfies students' requirements for professional learning, further education in foreign countries and employment. This paper thinks that the success of improving English learning lies in the improvement of teacher's accomplishments. This paper analyzes teacher's quality from six aspects and discusses the way to improve their qualities in the information age.
\end{abstract}

\section{Introduction}

Foreign language teaching should not only meet national needs, but it should also meet individual needs. One of the core tasks is to train qualified foreign language teachers. This paper mainly discusses the two problems-Which quality should college English teachers have? How to improve teacher's quality?

\section{Three New Requirements}

Higher education aims to cultivate talents who can adapt to the current social development. With the society changing fast, it is advisable to learn about the new changes before teacher's accomplishments will be discussed since teachers play an important role in education. The current social development means great change and new requirements for foreign language teaching.

\section{New Development Situation of Higher Education}

The National Program for Medium- and Long-Term Educational Reform and Development (2010-2020) put forward requirements clearly about building China into the country with strong higher education. Teaching quality improvement is regarded as the core task of higher education development. English, as one of the most important public courses, plays an important role in the cultivation of talents. Therefore, improving English teaching quality A Guide to College English Teaching proposes that college public English courses offering meet university students' professional learning, academic exchanges, further study abroad and employment, on the other hand, its offering should meet the national strategic demand and promote further reform and opening to the outside world as well as economic and social development. In a word, the latest development of higher education in China, the importance of promoting English teaching quality is discussed.

\section{New Requirements of College English Curriculum Teaching}

In a bid to adapt to the new situation of higher education, A Guide to College English Teaching presents new requirements to college English curriculum teaching. Instead of comprehensive ability, college English teaching aims to cultivate students' application ability. Given a vast territory, unbalanced regional development and varying English levels of freshmen, A Guide to College English Teaching set hierarchical teaching objectives, that is, basic objectives, improvement objectives and development objectives. Different levels of teaching objectives requires college English teachers' to achieve different teaching requirements. 


\section{New Requirements of New Information Environment}

In an ever-changing information times, modern information technology becomes an essential teaching means, which exerts deep influence on college English pedagogical reform. In the context of information environment, it is more convenient and easier to acquire and exchange information, so traditional teaching means fail to meet the needs of those who are willing to embrace new things. With a wider use of modern information technology in teaching, traditional teaching mode has been challenged greatly. New teaching modes are gaining popularity among teachers and students, such as mini lecture, the flipped classroom teaching, MOOCS and so forth.

With the three new requirements mentioned above, traditional teaching fails to keep pace with modern education in information age. It is widely acknowledged that teacher quality is one of the key elements which determine the success of educational reform. Since reform in college English teaching, many papers have been written to elaborate on improving English teaching. This papers mainly discusses college English teacher quality in information age.

The National Program for Medium- and Long-Term Educational Reform and Development (2010-2020) suggests building up the ranks of college English teachers with professional ethics, excellent professional work, reasonable structure and full of energy. So, with the current situation taken into account, this paper proposes that college English teachers should improve their quality from the following six aspects.

\section{Teachers' Accomplishments}

To meet the challenge taken by the social requirements, the writer holds that foreign language faculty should improve their teacher's quality from six aspects.

\section{Professional Competence}

Teachers are key to improving the teaching quality of college English. A solid knowledge of the English language enables teachers to impart professional knowledge. It is wise for English teachers to reinforce English subject knowledge and keep pace with the pace of the times. It is preferable to study new educational and teaching ideas to improve teaching ability.

\section{Teaching Ability}

A solid knowledge of the English language does not guarantee good teaching effect. In addition to abundant professional knowledge reserve, English teachers should pay attention to developing their English pedagogical knowledge. In actual teaching process, the ability to adjust the teaching contents, teaching methods and teaching means is indispensable to English teachers. Classroom is like an experimental base, so it requires teachers to base their teaching research on their actual classroom and teaching materials to study the problems and phenomena of classroom teaching. In the process of discovering, analyzing and solving problems, the teaching skills could be enhanced.

\section{Students- Oriented Awareness}

Aside from the requirements of subject knowledge and pedagogical knowledge, college English teachers need to build the awareness of student-oriented learning model. Efficient foreign language teaching is based on acquaintance with students' knowledge levels, interest, learning objectives, learning consciousness and learning patterns. It is wise for teachers to establish new students concept, with students' emotion, attitude, thought focused on and diverse learning needs learned about. unknown learning environment will be expanded and new knowledge added based on students' known knowledge levels.

\section{Modern Educational Technology Ability}

Teachers are able to get access to information by means of information technology and manufacture, organize, extract and create information with the aim of acquiring new knowledge. This concept is 
named information quality. In Information age, professional development of college English teachers includes new requirements: teacher's information quality will run through the process of teaching, learning and researching; teachers will be equipped with the ability of autonomous learning in information environment, information instruction capability and the ability of academic research in networked environment. College English teachers need to properly understand the integration of information technology and English teaching. Armed with advanced educational ideas, college English teachers need to maintain a good habit of integrating information technology with foreign language teaching in actual teaching.

\section{Life-Long Learning Idea}

To become a creative and thoughtful teacher, teachers should establish the concept of life-long learning and a learning teacher. Being a learning teacher is the requirement of learning society and internal driving force of life quality improvement and self-improvement. To renew ideas is the most important. It is good to read new publications on educational concept and excellent publications to update teachers' education ideas. Only learning teachers can surpass themselves to adapt human being's fast- growing and fast updating knowledge.

\section{Humanistic Quality}

College English Curriculum Requirements stipulates that college English curriculum is both instrumental and humanistic, which requires humanistic education should be integrated with college English teaching. On the other hand, language is the carrier of its culture. Since language learning involves cultural knowledge, culture teaching should be attached great importance to. It is the indivisibility of language and culture that makes enormous demands of college English teacher's humanistic quality. College foreign language teachers should act as Western culture researchers and Chinese noble culture transmitters (Tan, Cui, Luo, 2006). English teachers should strengthen humanity education while teaching the English language knowledge. It is necessary for foreign language instructors to look at Western and Chinese cultures from a dialectic view and exploit humanistic idea of education. Foreign language educational goal is to cultivate talents with both humanistic quality and scientific spirits, Western culture interpreters with both rich cultural knowledge instead of impersonal language users.

\section{Ways to Improve Teacher's Quality}

Teacher's quality somehow determines the quality of foreign language teaching. Given the importance of teacher's quality, the writer feels obliged to suggest some ways to improve teacher's accomplishments.

\section{Participating in Teaching Research and Reform}

To improve English teaching quality and teachers' self-development, college English teachers should keep learning something new and participate in teaching research. With the support and encouragement from school and colleagues, common progress of the team and individual self-worth will be realized.

\section{Showing Great Concern for Social Problems}

Like other humanities courses, college English curriculum should take educational responsibilities for cultivating university students' humanistic quality. It also aims at cultivating all-round talents with humanity spirits, a world vision and first-rate professional skills, which is what the university education emphasizes. It is advisable for foreign language teachers to go deep into the society to acquaint themselves with social hot problems and human destiny. In addition, English teachers need to pay close attention to such hot problems as world politics, energy development, environmental protection, cultural education, health care and so forth. 


\section{Striking a Balance between Teaching and Academic Research}

College English teachers should be fully aware that teaching is inherently linked with scientific research. Academic research provides strong support for teaching, at the same time, teaching is the invisible driving force of academic research. College English teachers feel obliged to apply the latest academic achievements to their classroom teaching. In addition to that, studying learning materials thoroughly and doing high-quality teaching will promote scientific research.

\section{Establishing Professional Development Goals}

College English teachers should continuously improve their academic performance matched with higher education level. They also need to keep reading academic publications as well as writing academic papers on language teaching. Due to the irrational structure of academic background, young teachers are encouraged to pursue doctor's degree with the aim of promoting professional competence and upgrading education levels.

\section{Summary}

This paper discusses what accomplishments should college English teachers have in the ever-changing information to age adapt to the current development situation of higher education. In addition, this paper analyzes diverse ways to improve teacher's quality. This paper holds that college English teaching in the context of information age means challenges as well as opportunities for English teachers. If college English teachers actively adapt to the new teaching requirements and the new situation of education development, they can provide university students with quality and developing foreign language education, which contributes a lot to cultivating strategic talents with international outlook, international communicative competence and high humanistic quality.

\section{References}

[1] Dinghuang. Shu, Social requirements and discipline construction of foreign language, J. Foreign Languages in China. 1(2017) 22-25.

[2] Tuanhua. Lu, Interpretation of the connotation of teachers' accomplishments and the way to improve, J. Harbin of Vocational \& Technical College. 4 (2016) 140-143.

[3] Shouren. Wang, Insisting on scientific perspective on college English teaching reform, J. Foreign Language World. 6 (2013) 9-13.

[4] Shouren. Wang, Interpretation of Guidelines on College English Teaching, J. Foreign Language World. 3 (2013) 2-10.

[5] Xi. Wu, On university English teachers' information literacy and professional development in information age, J. Yulin University. 2(2017) 113-116. 